\title{
Per oral substitution with 300000 IU vitamin D (Cholecalciferol) reduces bone turnover markers in HIV-infected patients
}

\author{
Rein Jan Piso ${ }^{1 *}$, Madeleine Rothen ${ }^{2}$, Jean Pierre Rothen ${ }^{3}$, Matthias Stahl ${ }^{1}$ and Christoph Fux ${ }^{4}$
}

\begin{abstract}
Background: Osteoporosis and bone fractures seem to be higher in HIV-infected Patients compared to the general populations. Moreover, bone turnover markers are increased in patients on antiretroviral therapy and vitamin $D$ deficiency is prevalent in HIV-infected patients. However, the influence of per oral cholecalciferol on bone metabolism in HIV infected patients is not well understood.
\end{abstract}

Methods: We measured the bone turnover markers in 96 HIV-infected patients: Bone specific alkaline phosphatase (BSAP), Pyridinoline (PYR), Desoxypyridinoline (DPD) and $25-\mathrm{OH}$ vitamin D. If $25-\mathrm{OH}$ vitamin D was below $75 \mathrm{nnol} / \mathrm{L}$ (87/96 patients), $300000 \mathrm{IU}$ cholecalciferol was given per os. 25OH-vitamin D and bone turn over markers were determinded 3 month later. $25 \mathrm{OH}$-vitamin D was corrected for circannual rythm $\left[y^{\prime}=y+17.875 * \sin \left(2 \frac{\pi}{365} *\right.\right.$ day +2.06$\left.)\right]$, whereas bone turnover markers were not corrected. The paired students t-Test was used to compare the two periods. No calcium supplementation or biphosphonate therapy was given.

Results: Corrected $25 \mathrm{OH}$-vitamin D levels increased significantly after supplementation $(42.7 \pm 26.61 \mathrm{vs} .52 .85 \pm 21.8 \mathrm{nmol} / \mathrm{L}$, $p<0.001$ ). After supplementation, bone turnover markers were significantly lower. The values decreased for BSAP from $21.31 \pm 14.32$ to $17.53 \pm 8.17 \mu \mathrm{g} / \mathrm{L}(p<0.001)$, PYR from $74.57 \pm 36.83$ to $54.82 \pm 21.43 \mathrm{nmol} / \mathrm{mmol}$ creatinine $(p<0.001)$ and DPD from $15.17 \pm 8.34$ to $12.61 \pm 5.02 \mathrm{nmol} / \mathrm{mmol}$ creatinine $(p=0.01)$.

Conclusions: After per oral substitution with cholecalciferol, bone formation as well as bone resorption markers decreased significant. We postulate a protective effect on bone structure with cholecalciferol supplementation.

\section{Background}

With the decline of opportunistic infections as consequence of antiretroviral therapy, life expectancy of HIV infected patients has prolonged remarkably [1]. In this newer era, in which HIV-infection is considered as a chronic, treatable disease, the focus on long time side effects of antiretroviral treatment as well as issues related to aging, partly aggravated by the HIV-infection itself, will become more and more important.

Recognized as a growing epidemic in the older, non HIV infected population, osteoporosis has become of particular interest to physicians treating HIV patients as well [2].

In HIV patients, an increased incidences of bone fractures has been observed [3], and it has been suggested

\footnotetext{
* Correspondence: jan.piso@spital.so.ch

'Department of Medicine, Kantonsspital, Olten, Switzerland

Full list of author information is available at the end of the article
}

that vitamin $\mathrm{D}$ deficiency $[4,5]$ and low bone mineral density $[6,7]$ are important pathogenic factors. Efavirenz has been shown to decrease vitamin D levels $[5,8]$, and antiretroviral treatment was associated with increased bone turnover [9] as well as decreases in bone mineral density $[10,11]$.

Levels of vitamin D are influenced by sunlight exposure and follow a seasonal rhythm [12]. Supplementation of low vitamin D levels has been widely adopted in HIVcare, but the benefits with respect to bone turn over, bone mineral density or fracture rate has not been clearly demonstrated. Most studies in non-HIV patients with osteoporosis have combined cholecalciferol and calcium supplementation $[13,14]$. A decrease in bone resorption as well as preservation of bone mineral density has been observed with a combination of cholecalciferol and calcium, but not with calcium supplementation alone [15].

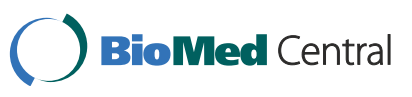


Low levels of vitamin D in HIV-patients compared to the general population are well described. However it is still not understood if this is due to the HIV infection itself or to traditional risk factors. Therefore, we compared vitamin D levels not with the general population, but with $\mathrm{HBV}$ and $\mathrm{HCV}$ monoinfected patients, postulating similar living conditions as well as chronic inflammatory status. Moreover, osteoporosis and low vitamin $\mathrm{D}$ level has also described in hepatitis $\mathrm{B}$ and $\mathrm{C}$ patients [16-19]. 25OH-vitamin D levels may also influence treatment outcome in Hepatitis C patients [20].

In patients with low $25 \mathrm{OH}$-vitamin D levels, we supplemented cholecalciferol and controlled bone turnover markers before and after supplementation. We choose a high dose pulse therapy primarily to limit pill burden, as it can be given at visit in the outpatient clinic.

\section{Methods}

Patients were recruited in the outpatient infectious disease clinic of Kantonsspital Olten. Baseline characters are presented in Tables 1 and 2. Patients were excluded if a start or switch in ART had been performed in the last six months, as this may interfere with $25 \mathrm{OH}$ Vitamin D levels and bone turnover. In patients with urgent need of antiretroviral therapy, no intervention data were collected for the same reason. Patients with Hepatitis monoinfection were excluded if treated with interferon. Dexa scans and nutrional data collection were not performed. At the follow up visit, questionnaire concerning overall physical health including specific questioning pain (bone fractures, nephrolitiasis) or nausea was filled out. Blood testing including liver, renal, metabolic and immunological parameters was also performed.

$25 \mathrm{OH}$-vitamin $\mathrm{D}$, bone specific alkaline phosphatase (BASP) were measured in serum, pyridinoline (PYR) and desoxypyrindinoline (DPD) crosslinks were measured in first morning urine. Patients with $25 \mathrm{OH}$-vitamin $\mathrm{D}<75$ $\mathrm{nmol} / \mathrm{L}[=30 \mathrm{ng} / \mathrm{mL}]$ were substituted with $300000 \mathrm{IU}$ cholecalciferol orally. 25OH-vitamin D, BSAP and crosslinks were controlled 3 month after supplementation. $25 \mathrm{OH}$-vitamin D was corrected for circannual rythm $\left[y^{\prime}=y+17.875 * \sin \left(2 \frac{\pi}{365} *\right.\right.$ day +2.06$\left.)\right][21]$, bone turnover markers were not corrected. According to the method published by Bolland who showed that the concentration of $25 \mathrm{OH}$-vitamin D follows a sine curve, we corrected the values for: baseline + amplitude $\times$ sine (angular frequency $\times$ day of the year + phase shift). Angular frequency was $2 \times \pi / 365$, and the phase shift is the translation from $x$ axis. As the minimum/maximum concentrations were in february resp. august, phase shift was calculated accordingly. Amplitude was calculated from minimum and maximum monthly mean values (before supplementation).

No calcium supplementation or biphosphonate therapy was given. Paired students t-test was used to compare the two periods. Unpaired Students t test was used to compare 25OH-vitamin D levels between HIV and $\mathrm{HCV} / \mathrm{HBV}$ patients.

Response to cholecalciferol was defined as $\geq 10 \%$ reduction in one or both of the two crosslinks. Calculation of factors that favour response was made by Chi-Square test for $2 \times 2$ tables. Correlations were made be linear regression with a significance level of $95 \%$.

\section{Ethics approval}

Treatment with cholecalciferol in patients with hypovitaminosis was considered as standard care, and decided by the attendant physician. So under Swiss regulations, this study did not need formal ethical approval.

\section{Results}

Differences between Hepatitis and HIV infected patients $25 \mathrm{OH}$-vitamin D, BSAP and crosslinks were measured in $96 \mathrm{HIV}$ infected patients. $25 \mathrm{OH}$-vitamin D levels were compared with $70 \mathrm{HBV}$ or HCV monoinfected patients. Baseline characters are shown in Tables 1 and 2. No difference in age between HIV and Hepatitis patients (42.5 \pm 9.1 vs. $42.8 \pm 11.2$ years, $\mathrm{p}=0.9)$ or gender was present $(39 / 70$ vs. $54 / 96$ male patients, $\mathrm{p}=0.9$ ). 47/70 Hepatitis patients had an HCV infection. No significant difference in $25 \mathrm{OH}-$ vitamin D levels could be found between HIV and non

Table 1 Baseline characteristics HIV patients

\begin{tabular}{|c|c|c|c|c|c|c|c|c|c|}
\hline & ART (\%) & No ART(\%) & $\mathrm{p}$-value & TDF (\%) & No TDF(\%) & p-value & PI & NNRTI & \\
\hline Men & $40(54)$ & $15(65)$ & \multirow[t]{2}{*}{0.38} & $26(48)$ & $14(73)$ & \multirow[t]{2}{*}{$p=0.054$} & $21(65)$ & $17(42)$ & \multirow[t]{2}{*}{0.03} \\
\hline Women & $33(36)$ & $8(35)$ & & $28(52)$ & $5(27)$ & & $10(35)$ & $23(58)$ & \\
\hline Total & $73(76)$ & $23(24)$ & & $54(74)$ & $19(26)$ & & $32(44)$ & $40(56)$ & \\
\hline Age \pm SD & $43 \pm 9$ & $43 \pm 9$ & 0.74 & $42 \pm 10$ & $43 \pm 11$ & $p=0.84$ & $44 \pm 9$ & $41 \pm 8$ & $p=0.08$ \\
\hline CD4 $<200$ & $10(50)$ & $10(50)$ & \multirow[t]{3}{*}{0.003} & $6(60)$ & $4(40)$ & \multirow[t]{3}{*}{$p=0.4$} & $6(60)$ & $4(40)$ & \multirow[t]{3}{*}{$p=0.3$} \\
\hline CD4200-350 & $23(92)$ & $2(8)$ & & $16(76)$ & $5(24)$ & & $7(30)$ & $15(70)$ & \\
\hline CD4 > 350 & $40(78)$ & $11(22)$ & & $32(80)$ & $8(20)$ & & $18(45)$ & $21(55)$ & \\
\hline
\end{tabular}


Table 2 Baseline characteristics

\begin{tabular}{lccc}
\hline & HIV (\%) & $\begin{array}{c}\text { Hepatitis } \\
\text { monoinfection (\%) }\end{array}$ & p-value \\
\cline { 1 - 3 } Men & $55(57)$ & $41(57)$ & 0.96 \\
\hline Women & $41(43)$ & $31(43)$ & \\
\hline Total & 96 & 72 & 0.75 \\
\hline Age & $43 \pm 9$ & $43 \pm 12$ & 0.82 \\
$\begin{array}{l}\text { Opiat consumption/ } \\
\text { substitution }\end{array}$ & $31(32)$ & $23(32)$ & 0.65 \\
\hline $\begin{array}{l}\text { Diabetes mellitus } \\
\text { HCV infection }\end{array}$ & $5(5)$ & $2(3)$ & $<0.001$ \\
\hline
\end{tabular}

HIV-patients $(45.3 \pm 29.7$ vs. $48.8 \pm 22.1 \mathrm{nmol} / \mathrm{L}, \mathrm{p}=0.4)$ (see Figure 1).

\section{Correlations between $250 \mathrm{H}$-vitamin D and bone turn over markers}

No correlations between $25 \mathrm{OH}$-vitamin D levels prior to substitution and bone turn over levels could be found. For BSAP, $r$ value was $-0.043 \pm 0,045 p=0.34$. Also for bone resorption markers, no correlation was present with $\mathrm{r}$ value of $0.001 \pm 0.12, \mathrm{p}=0.99$ for PYR and $-0.02 \pm$ $0.03, \mathrm{p}=0.54$ for DPD (See Additional file 1: Figure S1a).

\section{Substitution with cholecalciferol}

$87 / 96(90.6 \%)$ of the patients had a $25 \mathrm{OH}$ vitamin $\mathrm{D}$ level < $75 \mathrm{nmol} / \mathrm{l}, 10 / 96$ (10.4\%) were below $25 \mathrm{nmol} / \mathrm{L}$. Four patients had an urgent indication for antiretroviral therapy and were not included for control after substitution, as ART can influence vitamin D as well as bone turn over markers. 6 patients did not provide urine samples 3 month after substitution. In 77 patients analysis of the effect of cholecalciferol substitution could be done. 3 month after substitution, corrected $25 \mathrm{OH}$-vitamin D levels were significantly higher $(42.7 \pm 26.61$ vs. $52.85 \pm$ $21.8 \mathrm{nmol} / \mathrm{L}, \mathrm{p}<0.001)$. No patient had $25 \mathrm{OH}$-vitamin

25 OH Vitamin D in HIV vs Hepatitis Monoinfected Patients

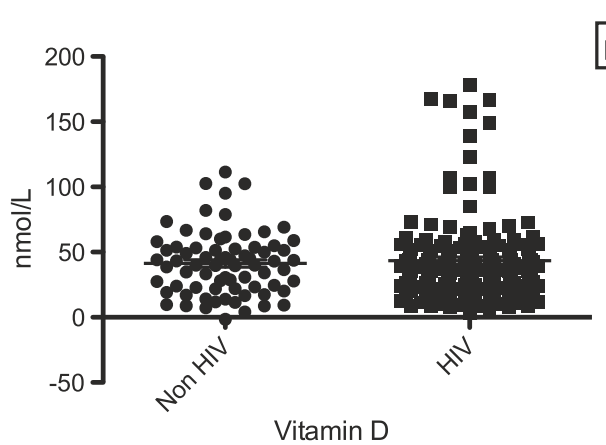

Figure 1 Differences between HIV and Hepatitis monoinfected patients.
D level in toxic range (>250 nmol/L) after substitution (See Figure 2).

\section{Bone turnover markers}

Bone turnover markers fell significantly after substitutions. The bone formation marker BSAP fell from $21.31 \pm 14.32$ to $17.53 \pm 8.17 \mu \mathrm{g} / \mathrm{L}(\mathrm{p}<0.001)$. Normal value for BSAP is $<14.3 \mu \mathrm{g} / \mathrm{L}$ pre- and $22.4 \mu \mathrm{g} / \mathrm{L}$ postmenopausal.

For bone resorption markers, PYR decreased from $74.57 \pm 36.83$ to $54.82 \pm 21.43 \mathrm{nmol} / \mathrm{mmol}$ creatinine $(\mathrm{p}<0.001)$ and DPD from $15.17 \pm 8.34$ to $12.61 \pm 5.02$ $\mathrm{nmol} / \mathrm{mmol}$ creatinine $(\mathrm{p}=0.01)$ (See Figures 2 and 3$)$.

\section{Factors for response}

We defined response to cholecalciferol as at least $10 \%$ reduction in either PYR or DPD. This is arbitrary but no data exist regarding response to cholecalciferol and bone turnover markers. 52/77 (67.5\%)patients did respond. We then correlated response with gender, HCV-infection, antiretroviral treatment, TDF-, PI- and NNRTI use, age, african descent, $\mathrm{BMI}<21$, smoker and $25 \mathrm{OH}$-vitamin $\mathrm{D}$ level $<30 \mathrm{nmol} / \mathrm{L}$. Antiretroviral treatment was correlated with better response to cholecalciferol (OR 2.76, CI $1.58-$ 4.53, $\mathrm{p}=0.002$ ), however the low number of patients without antiretroviral treatment limits the statistical value of this data. For other factors, no significance could be observed (see Table 3).

\section{Discussion}

Low bone mineral density (BMD) as well as insufficiency fractures are more common in HIV-patients compared to the general population $[3,11,22]$. Vitamin D deficiency is believed to be more frequent in HIV-patients [4,23]. We did not compare our patients with the general population, but with patients with a hepatitis $\mathrm{B}$ or $\mathrm{C}$ monoinfection and did not find a difference in vitamin $\mathrm{D}$ levels. Although it is known that Efavirenz can decrease vitamin D levels [8], life circumstances may be a more important factor for low vitamin D level than HIV-infection itself.

It is known that antiretroviral therapy increases bone turn over markers [9]. In accordance to Welz [8], we did not find a direct correlation between bone turnover markers and 25OH-vitamin D leves at baseline, but a significant decrease after supplementation. Results of cholecalciferol supplementation on bone turnover are conflicting. Contrary to our results, two recent publications showed an increase of BTM after high dose cholecalciferol supplementation [24,25], but these results were seen primarily in the first weeks after intervention, while at 16 weeks and one year, supplementation resulted in a decrease in bone turnover markers [26,27]. We did not measure or supplement calcium intake. Different results on BTM could be due to different calcium uptake, as the positive effect of active $1,25 \mathrm{OH}$ vitamin $\mathrm{D}$ 


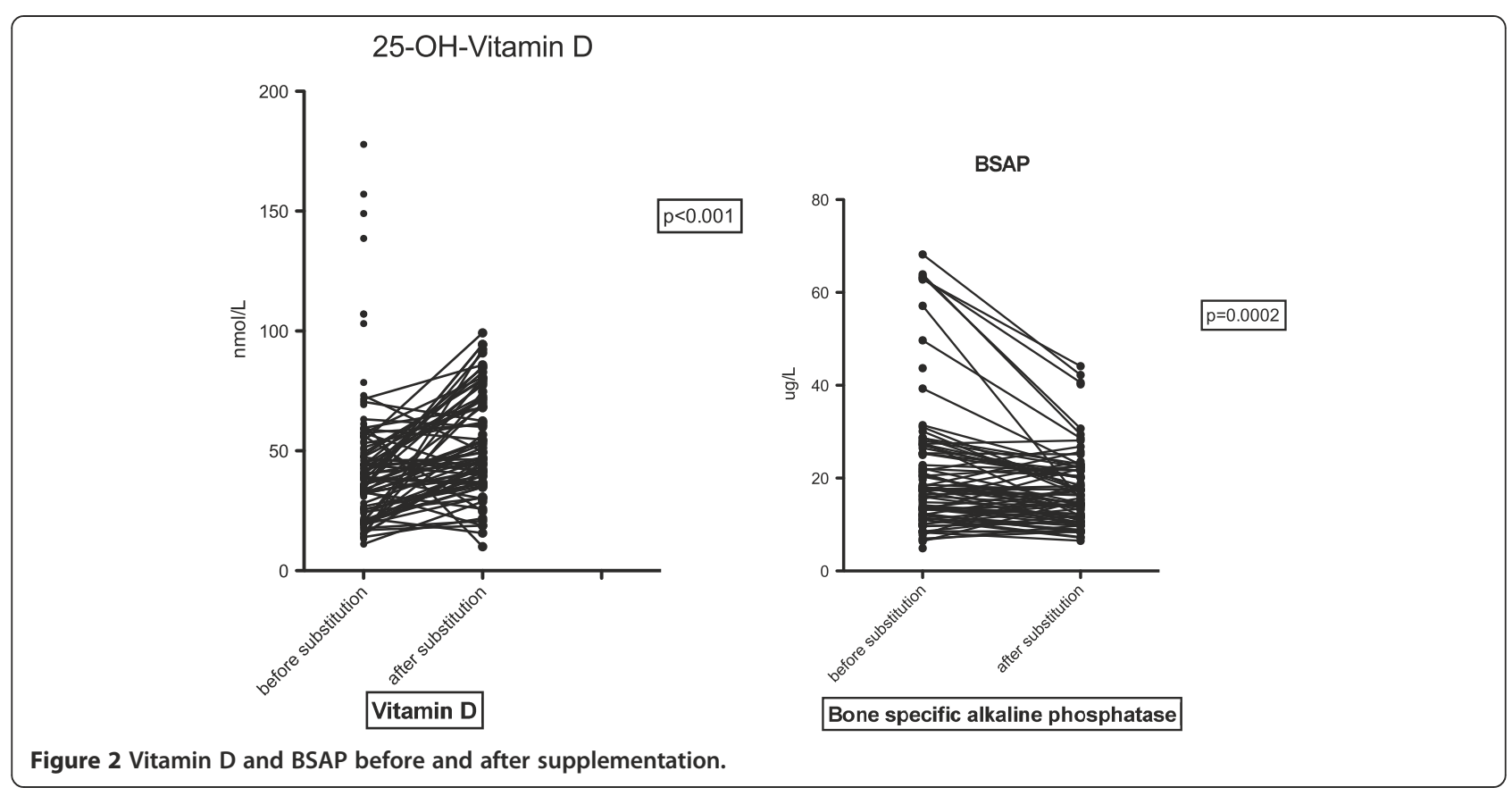

results in an increased calcium uptake, while the direct effect of vitamin D on osteoclasts and osteoblasts will enhance bone resorption and decrease bone formation [28]. In HIV-negative patients, most studies have been done in high risk populations with combined calcium and cholecalciferol supplementation [29]. These studies show a benefit with a reduction in fracture rate of $20 \%$ in patients in whom a target value of $>50 \mathrm{nmol} / \mathrm{L} 25 \mathrm{OH}$-vitamin D could be achieved [30]. It is suggested that $25 \mathrm{OH}$-vitamin
D levels should even be supplemented to $>75 \mathrm{nmol} / \mathrm{L}$ [31]. Even if the results of studies regarding fractures rate in HIV-patients yielded conflicting results and the effect of cholecalciferol is uncertain [32-36], we actually suggest cholecalciferol supplementation. We observed a decrease in bone resorption as well as bone formation markers 3 month after supplementation. A correlation between bone formation and bone resorption markers has be observed in other studies too $[9,37]$. We hypothesize

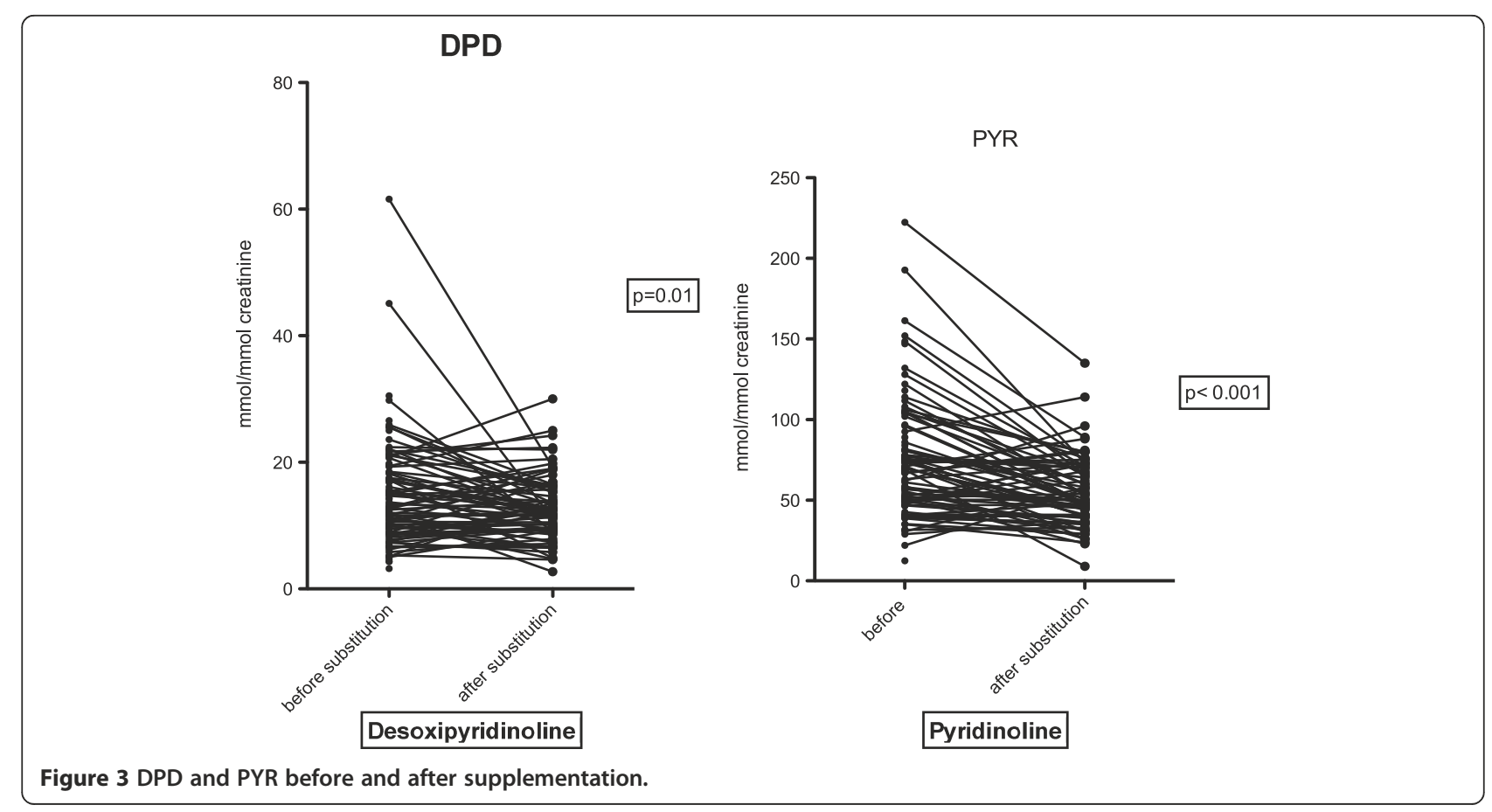


Table 3 Univariate analysis for response to vitamin D

\begin{tabular}{|c|c|c|c|c|c|}
\hline & Responder & $\begin{array}{c}\text { Non } \\
\text { responder }\end{array}$ & OR & $\mathrm{Cl}$ & $p$-value \\
\hline $\mathrm{HCV}$ & 25 & 8 & & \multirow{2}{*}{$0.78-3.23$} & \multirow{2}{*}{0.18} \\
\hline No HCV & 27 & 17 & & & \\
\hline IVDU & 23 & 6 & & \multirow{2}{*}{$0.86-4.23$} & \multirow{2}{*}{0.08} \\
\hline No IVDU & 29 & 19 & & & \\
\hline Treatment & 48 & 16 & \multirow{2}{*}{-2.76} & \multirow{2}{*}{$1.58-4.03$} & \multirow{2}{*}{0.002} \\
\hline No Treatment & 4 & 9 & & & \\
\hline TDF & 36 & 13 & \multirow{2}{*}{-1.61} & \multirow{2}{*}{$0.85-3.04$} & \multirow{2}{*}{3.04} \\
\hline No TDF & 16 & 12 & & & \\
\hline NNRTI* & 27 & 6 & & \multirow{2}{*}{$0.78-4.57$} & \multirow{2}{*}{0.14} \\
\hline$\overline{\mathrm{PI}}$ & 19 & 10 & & & \\
\hline Male & 28 & 14 & \multirow{2}{*}{-0.76} & \multirow{2}{*}{$0.4-1.46$} & \multirow{2}{*}{0.65} \\
\hline Female & 24 & 11 & & & \\
\hline African descent & 12 & 8 & \multirow{2}{*}{-1.34} & \multirow{2}{*}{$0.68-2.61$} & \multirow{2}{*}{0.4} \\
\hline No african descent & 40 & 17 & & & \\
\hline Age $<40$ & 18 & 10 & \multirow{2}{*}{-0.85} & \multirow{2}{*}{$0.44-1.64$} & \multirow{2}{*}{0.21} \\
\hline Age $>40$ & 34 & 15 & & & \\
\hline $\mathrm{BMI}<21$ & 7 & 2 & \multirow{2}{*}{-1.52} & \multirow{2}{*}{$0.43-5.4$} & \multirow{2}{*}{0.48} \\
\hline $\mathrm{BMI}>21$ & 45 & 23 & & & \\
\hline Smoker & 32 & 13 & & \multirow{2}{*}{$0.68-2.49$} & \multirow{2}{*}{0.42} \\
\hline Non smoker & 20 & 12 & & & \\
\hline Vit D 30-75 nmol/L & 38 & 17 & \multirow{2}{*}{-0.97} & \multirow{2}{*}{$0.47-2.01$} & \multirow{2}{*}{0.92} \\
\hline Vit $\mathrm{D}<30 \mathrm{nmol} / \mathrm{L}$ & 15 & 7 & & & \\
\hline Total & 52 & 25 & & & \\
\hline
\end{tabular}

*34/36 NNRTI patients received EFV.

that vitamin D may limit bone resorption, leading to a decrease in compensatory bone formation.

We used a high dose of cholecalciferol as "pulse therapy". This increase in $25 \mathrm{OH}$ vitamin D was significant but only about two third of that found in a recent study using 300000 IU intramuscularly [25]. This marked effect was also seen in another study from Iran [38] but our results were similar to a study from Australia [39]. High dose pulse therapy with cholecalciferol has previously been a regularly followed strategy but some authors advocate lower doses on daily base. Two rationales for daily or weekly cholecalciferol doses have been proposed. First, vitamin D has also an effect on muscle [40]. High levels of vitamin D could rapidly improve muscle function in frail patients in whom coordination is still reduced, leading to falls and fractures [41]. Secondly, vitamin D intoxication has been seen with pulse therapy [42]. Hypersensitivity to vitamin D has been correlated to mutations in CYP24A1 and these patients may have elevated vitamin D levels without supplementation [43]. As vitamin D had not been measured in most patients before supplementation, intoxication could be due to hypersensitivity rather than to high doses of cholecalciferol alone. As we only substituted patients with $25 \mathrm{OH}$-vitamin D deficiency, we think it is safe to give 300000 IU orally every 6 months. No toxic effects of vitamin D were observed. Even if life expectancy in HIV patients has markedly improved, frailty is still not a issue in most HIV-infected patients [44]. We therefore believe that the effect on muscle function may not lead to more falls. However, the optimal strategy for cholecalciferol supplementation has to be defined. Even if we could observe an increase in $25 \mathrm{OH}$-vitamin D levels, only about $20 \%$ of our patients did reach target value of $75 \mathrm{nmol} / \mathrm{L}$. Similar results has been shown in HIV patients given pulse [45] or continues low dose (4000 IU daily) supplementation [46].

We defined a decrease of $\geq 10 \%$ of either one or both bone resorption markers as response to cholecalciferol. This is an arbitrary definition but no cut-off values have been described. Even if we could find a significant overall decline in bone turnover markers, only 52/77 patients had a decrease in bone turnover markers, while 25 had not. We could not find a correlation with traditional risk factors or specific antiretroviral drugs and the response to Vitamin D supplementation in the univariate analyisis. Due to the lack of significance in univariate analysis, it is in our view inappropriate to perform a multivariate analysis, as these results cannot be interpreted properly. The same problem applies to the treated vs. non treated HIV-patients. Given the low number of patients without ART, the statistical significance compared to treated patients should be interpreted with caution. In Non-HIV patients, the effect of cholecalciferol on bone turnover markers shows conflicting results. While some studies show no effect despite benefit on BMD [47], others did show an amelioration of bone turnover $[48,49]$.

Our study has some limitations. It is a relatively small, open and not placebo controlled trial, and we did not measure calcium intake and sun exposure. Even if bone turnover markers are directly correlated with fracture rate independently of BMD [50], they do not substitute for the later. Thus far, we only showed a short term effect on bone metabolism, while ultimately reduced fracture rate is the primary endpoint of this medical intervention. Thus we propose larger, long term studies including DXA-scans and clinical events.

\section{Conclusion}

In summary, we showed that supplementation with high dose pulse therapy with cholecalciferol in HIV-patients with low $25 \mathrm{OH}$ vitamin $\mathrm{D}$ level resulted in a decline of bone resorption as well as in bone formation markers. As it has been shown that bone resorption and formation are linked, we postulate a protective effect on bone structure by cholecalciferol substitution. 


\section{Additional file}

Additional file 1: Figure S1a. Correlation between Vitamin D and bone turnover markers.

\section{Competing interests}

The authors declare that they have no competing interests.

\section{Authors' contributions}

RJP was main investigator, contributed to the design of the study, data collection, data analysis and interpretation and writing; MR contributed to design of the study, the data interpretation and revision of the manuscript; JPR contributed to the design, to the performances of urine analyses and revision of the manuscript; MS and CF contributed to the design and revision of the manuscript. All authors read and approved the final manuscript.

\section{Acknowledgement}

We like to thank Dr. Dave Crook, Radiology department, Kantonsspital Olten, for the linguistic corrections

\section{Author details}

${ }^{1}$ Department of Medicine, Kantonsspital, Olten, Switzerland. ${ }^{2}$ Department of Medicine, Regionalspital, Biel, Switzerland. ${ }^{3}$ Medical Laboratories Olten, Olten, Switzerland. ${ }^{4}$ Departement of Medicine, University Hospital, Aarau, Switzerland.

Received: 9 August 2013 Accepted: 2 December 2013 Published: 6 December 2013

\section{References}

1. Wada N, Jacobson LP, Cohen M, French A, Phair J, Munoz A: Cause-specific life expectancies after 35 years of age for human immunodeficiency syndrome-infected and human immunodeficiency syndrome-negative individuals followed simultaneously in long-term cohort studies, 1984-2008. Am J Epidemiol 2013, 177(2):116-125.

2. Castronuovo D, Cacopardo B, Pinzone MR, Di Rosa M, Martellotta F, Schioppa O, Moreno S, Nunnari G: Bone disease in the setting of HIV infection: update and review of the literature. Eur Rev Med Pharmacol Sci 2013, 17(18):2413-2419.

3. Young B, Dao CN, Buchacz K, Baker R, Brooks JT, HIV Outpatient Study (HOPS) Investigators: Increased rates of bone fracture among HIV-infected persons in the HIV Outpatient Study (HOPS) compared with the US general population, 2000-2006. Clin Infect Dis 2011, 52(8):1061-1068.

4. Dao CN, Patel P, Overton ET, Rhame F, Pals SL, Johnson C, Bush T, Brooks JT, Study to Understand the Natural History of HIV and AIDS in the Era of Effective Therapy (SUN) Investigators: Low vitamin D among HIV-infected adults: prevalence of and risk factors for low vitamin D Levels in a cohort of HIV-infected adults and comparison to prevalence among adults in the US general population. Clin Infect Dis 2011, 52(3):396-405.

5. Mueller NJ, Fux CA, Ledergerber B, Elzi L, Schmid P, Dang T, Magenta L, Calmy A, Vergopoulos A, Bischoff-Ferrari HA, the Swiss HIV Cohort Study: High prevalence of severe vitamin D deficiency in combined antiretroviral therapy-naive and successfully treated Swiss HIV patients. AIDS 2010 24(8):1127-1134.

6. Calmy A, Fux CA, Norris R, Vallier N, Delhumeau C, Samaras K, Hesse K, Hirschel B, Cooper DA, Carr A: Low bone mineral density, renal dysfunction, and fracture risk in HIV infection: a cross-sectional study. J Infect Dis 2009, 200(11):1746-1754.

7. Cazanave C, Dupon M, Lavignolle-Aurillac V, Barthe N, Lawson-Ayayi S, Mehsen N, Mercie P, Morlat P, Thiebaut R, Dabis F, Groupe d'Epidemiologie Clinique du SIDA en Aquitaine: Reduced bone mineral density in HIV-infected patients: prevalence and associated factors. AIDS 2008, 22(3):395-402.

8. Welz T, Childs K, Ibrahim F, Poulton M, Taylor CB, Moniz CF, Post FA Efavirenz is associated with severe vitamin D deficiency and increased alkaline phosphatase. AIDS 2010, 24(12):1923-1928.

9. Piso RJ, Rothen M, Rothen JP, Stahl M: Markers of bone turnover are elevated in patients with antiretroviral treatment independent of the substance used. J Acquir Immune Defic Syndr 2011, 56(4):320-324.
10. Stellbrink HJ, Orkin C, Arribas JR, Compston J, Gerstoft J, Van Wijngaerden E, Lazzarin A, Rizzardini G, Sprenger HG, Lambert J, Sture G, Leather D, Hughes S, Zucchi P, Pearce H, ASSERT Study Group: Comparison of changes in bone density and turnover with abacavir-lamivudine versus tenofovir-emtricitabine in HIV-infected adults: 48-week results from the ASSERT study. Clin Infect Dis 2010, 51(8):963-972.

11. Brown TT, McComsey GA, King MS, Qaqish RB, Bernstein BM, da Silva BA: Loss of bone mineral density after antiretroviral therapy initiation, independent of antiretroviral regimen. J Acquir Immune Defic Syndr 2009, 51(5):554-561.

12. Woitge HW, Knothe A, Witte K, Schmidt-Gayk H, Ziegler R, Lemmer B, Seibel MJ: Circaannual rhythms and interactions of vitamin D metabolites, parathyroid hormone, and biochemical markers of skeletal homeostasis: a prospective study. J Bone Miner Res 2000, 15(12):2443-2450.

13. Holick MF, Binkley NC, Bischoff-Ferrari HA, Gordon CM, Hanley DA, Heaney RP, Murad MH, Weaver CM, Endocrine Society: Evaluation, treatment, and prevention of vitamin D deficiency: an Endocrine Society clinical practice guideline. J Clin Endocrinol Metab 2011, 96(7):1911-1930.

14. Chung M, Balk EM, Brendel M, Ip S, Lau J, Lee J, Lichtenstein A, Patel K, Raman G, Tatsioni A, Terasawa T, Trikalinos TA: Vitamin D and calcium: a systematic review of health outcomes. Evid Rep Technol Assess (Full Rep) 2009, 183(183):1-420.

15. Zhu K, Devine A, Dick IM, Wilson SG, Prince RL: Effects of calcium and vitamin $\mathrm{D}$ supplementation on hip bone mineral density and calcium-related analytes in elderly ambulatory Australian women: a five-year randomized controlled trial. J Clin Endocrinol Metab 2008, 93(3):743-749.

16. Lin JC, Hsieh TY, Wu CC, Chen PJ, Chueh TH, Chang WK, Chu HC: Association between chronic hepatitis $C$ virus infection and bone mineral density. Calcif Tissue Int 2012, 91(6):423-429.

17. Schiefke I, Fach A, Wiedmann M, Aretin AV, Schenker E, Borte G, Wiese M, Moessner J: Reduced bone mineral density and altered bone turnover markers in patients with non-cirrhotic chronic hepatitis B or C infection. World J Gastroenterol 2005, 11(12):1843-1847.

18. Villar LM, Del Campo JA, Ranchal I, Lampe E, Romero-Gomez M: Association between vitamin $D$ and hepatitis $C$ virus infection: A meta-analysis. World J Gastroenterol 2013, 19(35):5917-5924.

19. Kong J, Ding Y, Zhang C, Fu Y, Du J, Lu C, Dou X, Chen Y, Li YC, Zhao Q: Severe vitamin D-deficiency and increased bone turnover in patients with hepatitis B from northeastern China. Endocr Res 2013, 38(4):215-222.

20. Petta S, Ferraro D, Camma C, Cabibi D, Di Cristina A, Di Marco V, Di Stefano R, Grimaudo S, Mazzola A, Levrero M, Scazzone C, Craxi A: Vitamin D levels and IL28B polymorphisms are related to rapid virological response to standard of care in genotype 1 chronic hepatitis C. Antivir Ther 2012, 17(5):823-831.

21. Bolland MJ, Grey AB, Ames RW, Mason BH, Horne AM, Gamble GD, Reid IR: The effects of seasonal variation of 25-hydroxyvitamin $D$ and fat mass on a diagnosis of vitamin D sufficiency. Am J Clin Nutr 2007, 86(4):959-964.

22. Anastos K, Lu D, Shi O, Mulligan K, Tien PC, Freeman R, Cohen MH, Justman J, Hessol NA: The association of bone mineral density with HIV infection and antiretroviral treatment in women. Antivir Ther 2007, 12(7):1049-1058.

23. Pinzone MR, Di Rosa M, Malaguarnera M, Madeddu G, Foca E, Ceccarelli G, D'Ettorre G, Vullo V, Fisichella R, Cacopardo B, Nunnari G: Vitamin D deficiency in HIV infection: an underestimated and undertreated epidemic. Eur Rev Med Pharmacol Sci 2013, 17(9):1218-1232.

24. Rossini M, Adami S, Viapiana O, Fracassi E, Idolazzi L, Povino MR, Gatti D: Dosedependent short-term effects of single high doses of oral vitamin d (3) on bone turnover markers. Calcif Tissue Int 2012, 91(6):365-369.

25. Etminani-Esfahani M, Khalili H, Jafari S, Abdollahi A, Dashti-Khavidaki S: Effects of vitamin D supplementation on the bone specific biomarkers in HIV infected individuals under treatment with efavirenz. BMC Res Notes 2012, 5(1):204

26. Bang UC, Kolte L, Hitz M, Schierbeck LL, Nielsen SD, Benfield T, Jensen JE: The effect of cholecalciferol and calcitriol on biochemical bone markers in HIV type 1-infected males: results of a clinical trial. AIDS Res Hum Retroviruses 2013, 29(4):658-664.

27. Herrmann W, Kirsch SH, Kruse V, Eckert R, Graber S, Geisel J, Obeid R: One year $B$ and $D$ vitamins supplementation improves metabolic bone markers. Clin Chem Lab Med 2012, 51(3):639-647.

28. Lieben L, Carmeliet G: Vitamin D signaling in osteocytes: Effects on bone and mineral homeostasis. Bone 2012, 54(2):237-243. 
29. Tang BM, Eslick GD, Nowson C, Smith C, Bensoussan A: Use of calcium or calcium in combination with vitamin $D$ supplementation to prevent fractures and bone loss in people aged 50 years and older: a meta-analysis. Lancet 2007, 370(9588):657-666.

30. Bischoff-Ferrari HA, Willett WC, Wong JB, Stuck AE, Staehelin HB, Orav EJ, Thoma A, Kiel DP, Henschkowski J: Prevention of nonvertebral fractures with oral vitamin $D$ and dose dependency: a meta-analysis of randomized controlled trials. Arch Intern Med 2009, 169(6):551-561.

31. Bischoff-Ferrari HA, Dietrich T, Orav EJ, Dawson-Hughes B: Positive association between 25-hydroxy vitamin $D$ levels and bone mineral density: a population-based study of younger and older adults. Am J Med 2004, 116(9):634-639.

32. Childs K, Kadish C, Branch-Elliman W, Fishman S, Mullen M, Branch A: Vitamin D can calcium supplements reverse the secondary hyperparathyroidism tha commonly ocurs. HIV Med 2009, 10(Suppl.1):36-37.

33. Havens P, Hazra R, Stephensen C, van Loan M, Rutledge B, Bethel J, et al: Vitamin D3 Supplementation Decreases PTH in HIV-infekcted Youth Being TReated wth TDF-containing Combination ART: A Randomized, Double-blind, Pacebo-controlled Multicenter Trial: Adult network Study 063 [abstract]. In 18th Conference ib Retroviruses and Opportunistic Infections. Boston, MA,USA; 2011. Abstract 80

34. Jacobson DL, Spiegelman D, Knox TK, Wilson IB: Evolution and predictors of change in total bone mineral density over time in HIV-infected men and women in the nutrition for healthy living study. J Acquir Immune Defic Syndr 2008, 49(3):298-308.

35. Yin MT, Shi Q, Hoover DR, Anastos K, Sharma A, Young M, Levine A, Cohen MH, Shane E, Golub ET, Tien PC: Fracture incidence in HIV-infected women: results from the Women's Interagency HIV Study. AIDS 2010, 24(17):2679-2686.

36. Van Den Bout-van Den Beukel CJ, Van Den Bos M, Oyen WJ, Hermus AR, Sweep FC, Tack CJ, Bosch ME, Burger DM, Koopmans PP, Van Der Ven AJ: The effect of cholecalciferol supplementation on vitamin D levels and insulin sensitivity is dose related in vitamin D-deficient HIV-1-infected patients. HIV Med 2008, 9(9):771-779.

37. Aukrust P, Haug CJ, Ueland T, Lien E, Muller F, Espevik T, Bollerslev J, Froland SS: Decreased bone formative and enhanced resorptive markers in human immunodeficiency virus infection: indication of normalization of the bone-remodeling process during highly active antiretroviral therapy. J Clin Endocrinol Metab 1999, 84(1):145-150.

38. Zabihiyeganeh M, Jahed A, Nojomi M: Treatment of hypovitaminosis D with pharmacologic doses of Cholecalciferol, Oral versus Intramuscular; an open labeled RCT. Clin Endocrinol (Oxf) 2012, 78(2):210-216.

39. Hackman KL, Gagnon C, Briscoe RK, Lam S, Anpalahan M, Ebeling PR: Efficacy and safety of oral continuous low-dose versus short-term high-dose vitamin D: a prospective randomised trial conducted in a clinical setting. Med J Aust 2010, 192(12):686-689.

40. Sato Y, Iwamoto J, Kanoko T, Satoh K: Low-dose vitamin D prevents muscular atrophy and reduces falls and hip fractures in women after stroke: a randomized controlled trial. Cerebrovasc Dis 2005, 20(3):187-192.

41. Sanders KM, Stuart AL, Williamson EJ, Simpson JA, Kotowicz MA, Young D, Nicholson GC: Annual high-dose oral vitamin D and falls and fractures in older women: a randomized controlled trial. JAMA 2010, 303(18):1815-1822.

42. Misselwitz J, Hesse V: Hypercalcemia following prophylactic vitamin D administration. Kinderarztl Prax 1986, 54(8):431-438.

43. Schlingmann KP, Kaufmann M, Weber S, Irwin A, Goos C, John U, Misselwitz J, Klaus G, Kuwertz-Broking E, Fehrenbach H, Wingen AM, Guran T, Hoenderop JG, Bindels RJ, Prosser DE, Jones G, Konrad M: Mutations in CYP24A1 and idiopathic infantile hypercalcemia. N Engl J Med 2011, 365(5):410-421.

44. Hoy J: Bone, fracture and frailty. Curr Opin HIV AIDS 2011, 6(4):309-314.

45. Giacomet V, Vigano A, Manfredini V, Cerini C, Bedogni G, Mora S, Borelli M, Trabattoni D, Zuccotti GV: Cholecalciferol supplementation in HIV-infected youth with vitamin D insufficiency: effects on vitamin D status and T-cell phenotype: a randomized controlled trial. HIV Clin Trials 2013, 14(2):51-60.

46. Longenecker CT, Hileman CO, Carman TL, Ross AC, Seydafkan S, Brown TT, Labbato DE, Storer N, Tangpricha V, McComsey GA: Vitamin D supplementation and endothelial function in vitamin D deficient HIV-infected patients: a randomized placebo-controlled trial. Antivir Ther 2012, 17(4):613-621.

47. Barnes MS, Robson PJ, Bonham MP, Strain JJ, Wallace JM: Effect of vitamin D supplementation on vitamin D status and bone turnover markers in young adults. Eur J Clin Nutr 2006, 60(6):727-733.
48. Lips $P$, van Schoor NM: The effect of vitamin D on bone and osteoporosis. Best Pract Res Clin Endocrinol Metab 2011, 25(4):585-591.

49. Prestwood KM, Pannullo AM, Kenny AM, Pilbeam CC, Raisz LG: The effect of a short course of calcium and vitamin $\mathrm{D}$ on bone turnover in older women. Osteoporos Int 1996, 6(4):314-319.

50. Robbins JA, Schott AM, Garnero P, Delmas PD, Hans D, Meunier PJ: Risk factors for hip fracture in women with high BMD: EPIDOS study. Osteoporos Int 2005, 16(2):149-154.

doi:10.1186/1471-2334-13-577

Cite this article as: Piso et al:: Per oral substitution with $300000 \mathrm{IU}$ vitamin D (Cholecalciferol) reduces bone turnover markers in HIV-infected patients. BMC Infectious Diseases 2013 13:577.

\section{Submit your next manuscript to BioMed Central and take full advantage of:}

- Convenient online submission

- Thorough peer review

- No space constraints or color figure charges

- Immediate publication on acceptance

- Inclusion in PubMed, CAS, Scopus and Google Scholar

- Research which is freely available for redistribution

Submit your manuscript at www.biomedcentral.com/submit
C Biomed Central 